УДК: 72.036

ББК: 85.11

DOI: $10.18688 /$ aa2111-08-63

\author{
K. A. Malich
}

\title{
Two Delegations of British Architects in the Soviet Union: Professional Contacts between British and Soviet Architects at the Beginning of the Khrushchev Thaw ${ }^{1}$
}

Professional contacts between Soviet and foreign architects remain a poorly studied area in domestic and foreign art history. At the same time, the extensive work that has been going on in recent decades in the field of studying the activities of All-Union Society for Cultural Relations (VOKS) and Soviet cultural international politics $[7 ; 2 ; 4 ; 10 ; 14 ; 19]$, and also a discussion about the specifics and role of the Soviet architectural practice of the 1930-1950s [5; 20], prompts to look at this plot with special attention. After all, the reasons, circumstances, and the very nature of professional communication between the Russian architects and their foreign colleagues help us to assess the peculiarities of the development of the Russian architectural school more objectively. In this article, we continue the conversation about the professional communication between Soviet and British architects, highlighting the period of the "thaw" as an important stage in the history of these relations. In this study the trips of British architects to USSR which took place in 1953 and 1955 are reviewed.

As S. V. Ward noticed in his profound study of British planning movement's Soviet connections «duality between rational learning and culturally constructed imagining is thrown into exceptionally sharp relief when studying Western encounters with the USSR» [20, p. 500]. Although some British architects considered the possibility of coming to the USSR in the hope of getting a commission, the majority arrived more out of curiosity. The shortcomings of the building infrastructure and the poverty of everyday life left an imprint on their perception of the new experimental architecture, causing skepticism and preventing the Soviet side from producing the experience it had hoped for by hosting foreign guests. However, in the 1940s, the context of the perception of the Soviet art has changed.

During the years of the Anglo-Soviet Alliance (1941-45), the sympathy for Russia appeared in Britain, which could even be called "unprecedented enthusiasm" [12, p. 253]. The exhibitions dedicated to Russia, the Eastern Front, and Anglo-Soviet friendship were held (Erno Goldfinger took part in their organization ${ }^{2}$ ), while the British people collected gifts for the Soviet people (Mrs. Clementine Churchill did this personally). Architectural issues were no excep-

The publication was prepared within the framework of the Academic Fund Program at HSE University in 2020-2021 (grant no. 20-04-029).

2 Royal Institute of British Architects (RIBA) Archive. The UK. London. AP 66/65. 
tion: during the war years, the Society for Cultural Relations between the Peoples of the British Commonwealth and the Union of Socialist Soviet Republics (SCR) established the exchange of architectural periodicals through VOKS. The British architects regularly (when possible in the wartime) received the "Architecture of the USSR" magazine. In response, the brochures and magazines from RIBA were sent to the Soviet Union ${ }^{3}$. In 1942, the RIBA magazine published an article dedicated to Soviet-British friendship, which quoted a radio speech by Viktor Vesnin: "While the struggle is going on, friendship with England is getting stronger" [1]. The leitmotif of all letters and discussions was the exchange of experience in solving common problems that now faced the architects of both countries: air defense and plans for the post-war reconstruction of destroyed cities. In 1945, RIBA awarded the gold medal to Viktor Vesnin. And the next year, Zholtovsky, Shchusev, and Mordvinov were elected members of the RIBA. The architects did not attend the dedication ceremony, but replied with letters of gratitude.

By this time, there were about 50 people in the architectural section of VOKS, among them - Pavel Abrosimov, Alexander Gegello, Boris Iofan, Alexey Dushkin, Mikhail Minkus, and Lev Rudnev. The president of the section was Karo Alabyan, and the secretary was David Arkin (the bulk of the official letters were addressed to him). In turn, in 1945, the Architectural and Planning Section at SCR began to work actively, which included Arthur Ling, Sir Charles Reilly, Berthold Lubetkin, and others. With the participation of SCR, they organized lectures and exhibitions; for example, in 1948, they held two photo exhibitions in London called "Architecture of the Peoples of the USSR" and "Architecture of Moscow". The correspondence with the Union of Architects of USSR also went through them. Immediately after the war, many letters had come: a student from Liverpool, eager to learn everything about architectural education in the USSR, or a Birmingham engineer requesting a copy of an article about tourist bases in "Architecture of the USSR", or architects who dreamed of subscribing to Soviet architectural magazines and establishing regular relations with young architects.

The English and Soviet architects exchanged books intensively: both sides were interested in materials related to urban planning and prefabricated housing. VOKS sent materials about precast concrete and plans for the reconstruction, but mainly books on the history of Russian architecture (which was also relevant after the war: talking about the heritage, we revealed the scale of losses during the war). On June 20, 1947, Professor of RIBA A.E. Richardson thanked David Arkin for the book about Tsarskoe Selo and noted that as a researcher of Russian architecture he sympathized with these "terrible losses"4.

It is obvious that the large-scale destruction of architectural monuments, as well as the task of quickly replenishing the lost housing stock - the problems of both the USSR and England, contributed to the interest in the exchange of experience. Soviet architects regularly received invitations to come to England right after the war. In 1946, Secretary of the International Federation for Housing and Town Planning E. E. Pepler invited Soviet architects to take part in the $18^{\text {th }}$ conference in Hastings and offered to join the Federation Council. The Russian specialists were unable to come, and they also failed to send the materials on Stalingrad requested by the federation. The Soviet architects did not attend the conference on April 28, 1947, in Paris either ${ }^{5}$.

Russian State Archive of Literature and Art (RGALI), ф. 674, оп. 2, д. 99, л. 29.

State Archive of the Russian Federation (GARF), ф.5283, оп. 15, д. 383, л. 24.

GARF, ф. 5283, оп. 15, д. 352, лл. 2, 11, 12, 14, 29. 
SCR wrote to Moscow that an exchange of delegations is needed in the nearest future. They asked to send at least a couple of people who could tell about the USSR's plans for the post-war reconstruction of cities. At the same time, it was emphasized that the written exchange of materials is nothing compared to the trip ${ }^{6}$. But no matter how many times Karo Alabyan asked to send a group of Soviet architects to Britain, given that "England has never been visited by Soviet architects"7, nothing worked. Not only the recommended composition (G. A.Simonov, A. V.Shchusev, A. I. Gegello, D. N. Chechulin, N. V.Baranov, D. E. Arkin, A. V. Vlasov, N.P. Bylinkin), but even Karo Alabyan himself was not given permission to travel. Chairman of the Committee for Architecture under the Council of Ministers of the USSR Grigory Simonov replied to VOKS that "due to the extensive restoration work carried out by the architects of the Soviet Union, it is not possible for Soviet architects to take part" in the trip to London ${ }^{8}$.

Only in the early 1950s were the Russian architects finally released on business trips abroad: in 1952 they made trips to Romania and the Czech Republic; in 1953, delegations were sent to Portugal, Finland, Romania, France, East Germany, Poland; in 1954, — to Poland, Greece, Hungary, and China. Foreign colleagues came to Moscow on return visits. It was at this time that the first working architectural trips between London and Moscow took place, laying the foundations for close professional communication over the next ten years. In general, if we consider cultural contacts, this period can be called a real "Indian summer" in Anglo-Soviet relations [13]. The genre and format of this essay does not allow covering all cases and forms of professional international communication between the architects, therefore we will consider the first two visits of British specialists to the USSR in 1953 and 1955. Firstly, we are interested in the program, which was developed by the host to show the achievements of Soviet architecture; secondarily, we will examine guests' requests, as well as the interpretation of their impressions.

The first trip took place in September, 1953: a group of ten British architects made a threeweek journey to the USSR at the invitation of the Union of Architects of USSR, with the participation of VOKS as the chief operator of the tour. The group included the director of the Construction Center F. R. Yerbury (the former secretary of the London Architectural Association who had already visited the USSR in the 1930s [15]), architects F. P. Tindall, B. Lubetkin, F. R.S. Yorke, C. Penn, and A. Douglas Jones (note, all by convictions were representatives of the Modern movement). However, the local Union's branches greeted the British architects as "a delegation of architects from RIBA"9.

The travel route was long. The flight to Moscow took several days: via Brussels, Prague, and Minsk. The travelers spent several days in Prague, but walks around the city were not allowed. In Minsk, they went through customs and flew from there on a special flight to Moscow. In the capital of the USSR, the guests were shown the Kremlin, Gorky Street, the Moscow Metro ("Taganskaya", "Komsomolskaya" stations), the river port in Khimki, Gorky Central Park of Culture and Leisure, and the new buildings at the beginning of Leninsky Prospekt. The guests visited the Construction exhibition, the Moscow Architectural Institute, and the Moscow City Executive Committee. Alexander Vlasov, head of the Moscow Architectural and Planning De-

GARF, ф. 5283, оп. 15, д. 383, л. 48.

GARF, ф. 5283, оп. 15, д. 383, лл. 49-50.

GARF, ф. 5283, оп. 15, д. 383, л. 19.

RGALI, ф. 674, оп. 3, д. 623, л. 34 . 
partment, personally showed the guests his workshop and the construction site of the Moscow State University (together with Lev Rudnev), and talked about the urban planning in the capital. The extensive cultural program included several trips to the Bolshoi Theatre ("The Swan Lake", "Ivan Susanin", "Ruslan and Lyudmila"), a trip to the Union of Architects Recreation Center in Sukhanovo, and film screenings ("Tractor Driver", "Stalingrad").

From Moscow, the group was taken to Stalingrad. Vasily Simbirtsev, the chief architect of the city, personally showed the hydroelectric power station, the Volga-Don Canal, the Children Railway, the new embankment improvement, and the building of the regional party school. After Stalingrad, the delegation went to Rostov (general short tour), Yerevan (with an emphasis on the Central Market, Republic Square, the Armenian National Academic Theatre of Opera and Ballet), Kiev (inspection of the historical part and a visit to an exemplary collective farm), and, finally, Leningrad. In Leningrad, the British guests were shown the central ensembles, the Hermitage, the Russian Museum, Peterhof, Pavlovsk, and Tsarskoe Selo. The separate part of the program was the visit to residential quarters in the area of the Narva Triumphal Arch and Stachek Avenue. Finally, the group attended "Othello" at the Kirov Theater.

In total, 175.5 rubles were spent on the reception of British architects in 1953, according to the Union of Architects of USSR' reports ${ }^{10}$. The members of the British delegation were given 188 books on Russian architecture and 660 photos on Soviet architecture ${ }^{11}$. These figures, however, do little to illustrate the generous hospitality with which the British guests were received in September of 1953. They were lodged in the suites of the "National" Hotel. The cars arranged for them in Moscow were "ZIM-12" limousines. In the Bolshoi Theater, they were seated in the boxes next to Malenkov, Molotov, and other members of the government. But especially emotionally, the members of the delegation describe their experience related to food. F.R.S. Yorke several times, distracted from the architectural agenda, tells in his travel essay about black and red caviar, borscht, sandwiches, lamb chops, sturgeon, and in general about long dinners when people rose from the table long after midnight [21, p. 401]. The inability to walk freely around Moscow on Sunday upset the British colleagues, but that was compensated by gastronomic experiences. This annoying news "does not spoil the dinner". And for breakfast, before the morning omelet, vodka, salmon, and caviar were served. The Sunday meal did not end there, the guests were taken to Sukhanovo, where a "dinner far too big to eat; after three hours of hors-d’euvre the soup is quite sufficient, and the salmon and the steak too much, even for us" [21, p. 404].

What can we say about the warmth with which the travelers describe Stalingrad and Yerevan, where, obviously, the atmosphere was much more relaxed. Simbirtsev drove them along the Volga; in Yerevan, a dinner with barbecue in the house of a local Armenian architect was organized (with a slideshow about Armenian architecture). A visit to a cognac factory, a picnic in the mountains and dancing untill 3 a.m. turned a day in Yerevan into "a specially good day". Several photographs of the "vodka session", published among the photographs with architectural landmarks in the Yorke's report, explain why in the future, trips to the Soviet Union for tourists from European countries were perceived as an "alcoholic tour", which worked for the image of a special Russian friendliness as well [3, p.68].

RGALI, ф. 674, оп. 3, д. 2125, л. 13.

11 RGALI, ф. 674, оп. 3, д. 1307, лл. 23-25. 
However, one should not think that local cuisine overshadowed the main purpose of the trip: acquaintance with the modern Soviet architecture. First of all, the British architects were interested in plans for the development of large cities, new technical equipment, and projects of residential buildings. The reports on the Russian tour were prepared by the participants of the trip, Douglas Jones [9] and F. R. S. Yorke [21], very quickly and published in October-December, 1953. Most of the architectural impressions were associated with Moscow.

The first thing that struck guests in Moscow was the incredibly wide streets. Frank Yerbury, who visited the city in 1932, recalled that the streets were narrow then, covered with cobblestones, and there were many wooden houses around. In Moscow, Leningrad, and Kiev, the travelers noted green boulevards along the main avenues, planted during the reconstruction. And Gorky Central Park of Culture and Leisure was even compared to pleasure gardens (from the Englishman's side, of course, it's a very high assessment of landscape design). The second feature is the extraordinary cleanliness of Moscow streets, and especially the order in the subway, where you cannot smoke, there is no rubbish, the pavilions are better illuminated, and the escalators are faster than in the London Underground. They were also impressed by the system when the arrangement of lobbies, in which huge halls connect different platforms. And the third thing that made a really serious impression (except, for obvious reasons, Stalingrad) was the extremely fast pace of restoration work in all cities during the post-war reconstruction. Practically, there seemed to be no evident traces of war. British travelers sincerely noted the level of restoration of historical monuments and the professionalism of the restorers. Moreover, if the style and interiors of the Kremlin caused skepticism, the climate control and maintaining of a constant level of humidity and temperature inside the Annunciation and Assumption Cathedrals was considered as a respectful approval. They compared the progress of reconstruction in the Soviet Union with the situation in Great Britain: restoration, perhaps, turned out to be the only area in which they witnessed the superiority of the Russian masters. The reviews of modern architecture were different.

With particular interest, British colleagues studied how the working process was organized, what was in the competence of the chief architect, and how the orders were distributed. They specifically noted that urban planning had not been singled out in educational institutions as a separate profession. They also noted that, in the workshops, different typologies of buildings were designed simultaneously. The visit to Vlasov's workshop, which the British described as "a charming and unassuming man not unlike Winston Churcill to look at", was very fruitful. The guests discussed the ten-year plan for the reconstruction of Moscow, took photos of models and sketches showing the development of various urban areas. Together with Vlasov, they examined one of the largest construction sites - the building of the Moscow State University. The delegation highlighted the fact that third of the employees at Vlasov's workshops were women.

Among the technical innovations, special attention was drawn to pre-fabricated floors for working class flats: a pre-stressed concrete job with parquet finish in two layers, springs, and deadening between. However, neither technical inventions, nor the speed of the construction of a residential apartment building (6-8 months) softened the overall negative impression of the level of the residential architecture. The English travelers found the street plans too dull, the facades - monotonous and cumbersome. Vlasov explained, that Soviet architects were trying to avoid monotony with the help of details (bay windows, decoration elements), but this 
was interpreted by the guests as too formal. And although the absence of private property gave tremendous advantages in the construction of mass housing, the Russian architects did not take advantage of it: the typical elements and the decoration were of poor quality, the furniture inside the apartments looked terrible, the layouts were inconvenient (although the guests were clearly shown large apartments - they list two bedrooms, kitchen, living room, dining room, kitchen, and maid's room).

It was striking that in Vlasov's workshop, there were books on Italian architecture everywhere. The students in Moscow and Leningrad were "obsessed" with classicism, taught (as they were told by colleagues who graduated from the Academy of Arts in 1908 and 1914) in exactly same way as before the revolution [9, p. 687]. Lev Rudnev was characterized by English colleagues as delightful, but they spoke with great skepticism about his interiors and the classical portico of Moscow State University. They called that style of Soviet architecture "People's Realism", drawing a comparison with England of the Victorian era: the country was actively developing, it had vitality, power, tremendous technical achievements, but anachronisms were still popular in architecture. The English architects named the passion for decoration "Byzantine" and wondered, why the Russian people abandoned constructivism, opting for tradition (though they called Le Courbusier's Tsentrosoyuz Building "pretty grim"). Douglas Jones suggested that the Russians would have to take a different approach to modern architecture in the future. First, because there will be an increase in the development of prefabrication methods. Second, the shop window will become more and more important because the increase of modern trade will require large showcases and transparent lower floors. Third, "with the intellectual development of the Russian people, they may demand a more adventurous, aesthetic approach to their architecture" [9, p. 687]. This reasoning seems arrogant, although there is some uncertainty in the author's words: "I think it is probable that they are working to a broadly based but preconceived aesthetic formula which attempts to take account on tradition which constructivism does not, but which is entirely transitory. By saying this, I am not trying to fool myself that our architecture is anything but transitory, too. If "constructivism" is rejected, and as we have not got the necessary scientific knowledge to build the architecture based on human need, then the only remaining alternative is to do what the Russians are doing ..."

Perhaps the problem was that most of the architects in the English group were representatives of the Modern Movement, members of MARS. After the war the discussion intensified about which direction to give preference in the process of Reconstruction - the International style (which had difficulty making its way in Great Britain on the eve of the war), or more traditional practices. It was important to prove the obvious advantages of modern architecture in this situation. The experience of the USSR convinced them of the correctness of the chosen path. In the October issue of "Architect's Journal" (1953), photographs of the Komsomolskaya metro station and a view of the terrace of the 62nd Army Embankment in Stalingrad were published with the caption: "However depressed we may be by some of the reconstruction in our cities we can, at least, be grateful that none of our post-war neoclassical monuments was designed to toe a party line. We are reminded of the good fortune that gives us freedom (even if we do not always use it) to break with tradition in our buildings ..." [19, p. 398].

The British architects were surprised that in Stalingrad, where the housing problem was the problem number one, big budgets are spent on the construction of public buildings, the 
Planetarium, embankments (F.R.S. Yorke calls this a phenomenon common to the USSR in general [21, p. 402]). The irritation was probably caused not so much by the typology (the memorial character of the embankment in Stalingrad - the city which survived the catastrophic destruction - was obvious), but precisely by aesthetic preferences. And this applied precisely to modern architectural practice, since the historical heritage of Leningrad, which reminded the British of their native neoclassicism, was called by the guests "surely the richest part of the world in the $18^{\text {th }}$ century architecture".

Berthold Lubetkin, who participated in the trip, in his essay on Soviet architecture seemed to be trying to find an excuse for the reason why the avant-garde architecture experiment failed in the Soviet Union. He emphasizes its paper nature, utopianism, and the impossibility to implement, reducing everything to the lack of technology in a backward industry, which led to the "falsification" of technologies [15, p.263]. "All the aggressive self-assertion with which the functionalists enunciated their creed could mask neither the barrenness of their doctrine nor the sterility of their practice. The few remaining buildings of that period near witness to it... But the public was no longer to be ignored: the public had become the patron, and now loudly voiced its disapproval and impatience with both the theory and the practice of functionalism" [15, p. 263].

The question of the Soviet architects' aesthetic preferences had been raised by British colleagues before. When in May 1947, the "Architectural Review" published the texts on the Soviet post-war reconstruction prepared by D. Arkin, A.Bunin, and N. Bylinkin, a controversy erupted. Many English specialists thought that the Soviet architects were returning to eclecticism, while the language of modern architecture was becoming relevant throughout the world. Some British architects defended the Soviet architecture, but everyone was worried about one question, what is the aesthetic policy of Soviet architects and in particular what is their attitude to "eclecticism" and to the modern architectural movement". This question was raised by Andrew Boyd in his text "Marxism and Modern Architecture", which was send to VOKS ${ }^{12}$. Boyd continued: "these questions would not merely satisfy curiosity. It might be a real help to many of those who are now re-examining their architectural beliefs. The original inspiration of the modern movement has partly passed and its disappointing ill-effects have been increasingly noted"13.

It is significant that the members of the second delegation, which came in 1955 as the British Housing Mission, commented everything softer, with less sarcasm. Although some of the impressions were the same. The program of reception was drawn up by the architectural section of VOKS, taking into account the wishes of the British side ${ }^{14}$. The group visited the USSR in September 1955, and officially, it was a return visit to the arrival of Soviet architects in the spring of the same year.

In Moscow, the tour included Gorky Street, Soviet square, Leningrad highway, Khimki port, Mayakovskogo square, Smolenskaya square, Gorky Central Park of Culture and Leisure, Sparrow Hills, Moscow State University, Moscow Underground. The British group visited the Exhibition of Achievements of National Economy, the new restaurant "The Golden Ear" (3o-

GARF, ф. 5283, оп. 15, д. 407, л. 4.

GARF, ф. 5283, оп. 15 , д. 407, лл. $2-4$.

RGALI, ф. 674, оп. 3, д. 1321, лл. 1-9. 
лотой колос), The Bolshoy Theatre. Since the members of the delegation were interested in new residential construction, new technologies, and the production of reinforced concrete products, professional visits were organized to the Moscow House of Architects, to the Deputy Chairman of the State Committee for the Construction, to the Chairman of the City Administration of Moscow, and to the head of the Main Department for Housing and Civil Construction (Glavmosstroy) Vladimir Promyslov. The Executive Secretary of the Board of the Union of Architects of USSR Pavel Abrosimov described to the delegation the Moscow development plan. The guests were shown the All-Union Construction Exhibition, the Lyubertsy Electromechanical Plant, and the Central Research and Design Institute of Steel Structures. The British architects were acquainted with the large-panel construction method in the pavilions of the Building Exhibition and on Peschanaya Street.

After Moscow, like the previous delegation, the British architects went to Stalingrad. Here they were met by Vasily Simbirtsev who spoke about the restoration of the city. They were shown the Museum of Defense of Tsaritsyn-Stalingrad, the House of Technology and the Red October plant, the Planetarium, the residential quarters for the Red October and the tractor plant workers, the theater, the railway, and river stations. A documentary about the Battle of Stalingrad was shown at the House of Architects. The British delegation rode a boat along the Volga-Don Canal to the third lock, examined the Stalingrad hydroelectric power station. The architect Farshaw, upon special request, examined the new hospital. From Stalingrad, they flew to Sochi, where they studied the sanatorium construction, the Arboretum, and visited the resort of Matsesta, Lake Ritsa, and Gagra. Then they returned to Moscow, where part of the group visited the workshops of Mosproekt, and Farshaw - the buildings of the Botkin hospital. The British specialists were also taken to Sukhanovo, and to the Ostankino estate. The Kremlin and the mausoleum were included in the program as well.

Finally, at the end of the tour, the guests went to Leningrad, where a general excursion awaited them (Dekabristov Square, Summer Garden, Revolution Victims Square (now the Field of Mars), Smolny, Palace Square). Then, there followed a conversation about housing construction and city reconstruction with the Chairman of the Leningrad City Executive Committee and a visit to the Faculty of Architecture of the Academy of Arts. The British delegation visited the Kirov stadium, the new construction in the area of Stalin (now Moskovsky) Avenue, the large-panel house on Shchemilovka. Finally, the program included the Kirov Theater, the Hermitage, and Peterhof. The British delegation returned home through Helsinki.

In March 1956, the members of the delegation J. H. Forshaw, R. C. Bevan, and S. W. C. Phillips shared their impressions of the trip at a meeting at the Royal Institute of British Architects [17]. All the participants in the conversation noted the very warm welcome they received from the Russian architects. They were also struck with the difference with which Mr. Forshaw (the chief architect to the Ministry of Housing and Local Government and to the Ministry of Health) and Mr. Bevan (Bachelor of Science, The Building Research Station) had been treated. Mr. Phillips supposed that this was the "recognition of the status of British architecture, as well as an expression of the great importance which the Soviet Union attaches to professional and technical pursuits" [17, p. 188]. Everyone noted a very busy program, but that was not enough to fully understand the issues of organizing the construction business in the USSR. The Russian specialists at factories and institutes told everything very generously and in detail, but a lot of 
time was spent on an interpreter, so they did not manage to find out everything. In addition to a detailed story about residential architecture, standardized prefabricated concrete construction, materials used for walling, the interaction between architects, builders, and factories, as well as about the organization of design institutes and the Building Exhibition, the British architects have also highlighted several specific features.

The scales of the dwelling buildings are enormous. In the standardized systems, the techniques of handling and assembly have secured an enormous output. In many departments, women operate heavy machines. Prefabricated components of all dimensions are produced, including staircases and internal bathrooms. At the same time, this leads to uniformity and monotony of the pattern. The output of the huge factories cannot be controlled as well. The patterns are even unsuited to a programmed factory output. Inappropriate design is followed by the high cost of building and misuse of materials. Though they have seen living rooms used for several people or even two families (because of great need), general space standards were considered to be high. As to the quality of work, it was described as "rough but not careless", when bad finishing application was a trouble and tiles, paint, and other materials were of "inferior" quality [17, p. 184], especially in comparison with the old buildings. Only plastering undertaken entirely by women showed progress.

Mr. Bevan was also impressed by the scope and high level of the research work in building industry. He describes, for instance, an artificial sky that he was shown in one of the laboratories. The brightness of the sky could be varied to stimulate variations of the actual sky, model buildings were placed inside to study the possible light conditions. The testing machines for reinforced concrete columns, the experiments with thermal insulation, fire resistance materials, and the sound transmission determination of moisture gradients were also of great interest to the English specialists. Though the great deal of work on building research was done by the Russians, Mr. W. Allen mentioned that the research activity was not reflected in the variety of building methods used in practice.

The guests also paid attention to the great importance attached to the preservation of the historical buildings in Russia. Extensive, very delicate, and creditable restorations have been carried out by the architects and historians of special competence. Mr. Forshaw even wondered why the same care had not been afforded to the contemporary civil planning).

It is curious that in the Union of Architects of USSR report, ${ }^{15}$ the critical remarks of the British colleagues were recorded in much more detail, which is evidence of the sincere interest of the Russian side in objective comments from the outside (by the way, the British delegates in the conversation note the lack of awareness of Russian architects about what is happening abroad [16, p. 188]). The report says that British experts expressed the opinion that in order to save money in residential construction, it would be possible to reduce the height of the ceiling from 3 to $2.5 \mathrm{~m}$, reduce the width of the stairs, and avoid excessive consumption of wood by narrowing door straps and window sashes. At the same time, it was desirable to improve the quality of finishing work and interior decoration of apartments. The guests drew attention to the style of buildings, which lead to oversaturation of facades with details, which also increased the cost of the construction. The authors of the report emphasized that of all the metro stations,

15 RGALI, ф. 674, оп. 3, д. 1321, лл. 1-9, 20-25. 
the British liked the ones without the oversaturation of decor (Sverdlov square, Kaluzhskaya, Kurskaya). The outer cladding of wall panels with ceramics, which foreign colleagues proposed to replace with concrete elements, also seemed inappropriate. And the size and luxury of the decoration to the detriment of hygiene standards (plush curtains, for example) of the new sanatoriums in Sochi caused absolute bewilderment. The members of the delegation wanted to receive schematic plans of Russian cities after the reconstruction, which caught the Russian side by surprise: it turned out that there were simply no such maps. It was recommended to urgently make maps similar to the scheme of London that the British specialists brought as a gift to Soviet architects. The report also contains positive feedback from the guests - about large-panel construction, about the timing of construction work, about the convenience of the Moscow metro, the vastness of new avenues, landscaping in Stalingrad, and, of course, about the level of restoration projects.

The emphasis in this document seems to be precisely on criticism of excesses, as if the authors were calling their British colleagues as witnesses, defending the new line that became official in Soviet architecture in the mid-1950s, (that in fact existed long before the Khrushchev reforms began [11]). By the way, the famous decree No. 1871 "On the elimination of excesses in design and construction" was issued on November 4, 1955, already a month and a half after the arrival of the British delegation and before the report prepared by the Union of Architects. The style of the official report, of course, does not allow deciphering the true emotions of Russian architects. It is difficult to discern the drama behind the preserved archival documents, which developed against the backdrop of a dispute over style and aesthetic preferences. But we can definitely say that the scope of the postwar reconstruction and the importance of industrialization in a building sector, as well as the need of technical improvement, have made both the Soviet and British sides to come closer to each other, to compare their own experiences, to get acquainted with technical innovations, and to debug the exchange of information. In May, 1955, Pavel Abrosimov sent a letter to the Central Committee of the Communist Party of the Soviet Union with a request "to resolve the issue of broader familiarization of the creative and scientific personnel of Soviet architecture with foreign architectural and construction practice and the outstanding values of world architecture", since "the extremely weak acquaintance of Soviet architects with the achievements of progressive architectural and construction practice in foreign countries negatively affects their professionalism and practical activities" ${ }^{16}$. The British side, represented by RIBA and SCR, also regularly and persistently invited Soviet specialists to England to exchange experience, listening lectures on Soviet architectural practice. The momentum of the first trips in 1953-1955 will predetermine this mutual interest for a whole decade. The return visit of Soviet colleagues will be finally organized in 1958 [7]. The results of this trip deserve a separate research, as the documents from both Soviet and British archives shows an extremely variety of impressions and emotions.

16 RGALI, ф. 674, оп.3, д. 241, лл. 14-16. 


\section{References}

1. Anglo-Soviet Bonds in Architecture. Journal of the RIBA. 1942, August, p. 164.

2. Bagdasaryan V.; Orlov I.; Shnaidgen J. Sovetskoe zazerkale. Inostrannyy turizm v SSSR v 1930-1980-e gody (The Soviet Looking Glass. Foreign Tourism in the USSR in 1930-1980). Moscow, Forum Publ., 2007. 255 p. (in Russian).

3. Bagdasaryan V. Intourist as an Ideological Actor of the Cold War. Sovremennye problemy servisa $i$ turizma (Contemporary Problems of Service and Tourism), 2016, vol. 10, no. 4, pp.63-70 (in Russian).

4. Caute D. The Fellow Travellers. Intellectual Friends of Communism. New Haven, Yale University PressPubl., 1988. $420 \mathrm{p}$.

5. Cooke C. Beauty as a Route to 'the Radiant Future': Responses of Soviet Architecture. Journal of Design History, 1997, vol. 10, no. 2, pp. 137-160.

6. Cook I. R.; Ward S. V.; Ward K. Postwar Planning and Policy Mobilities through the Iron Curtain. International Journal of Urban and Regional Research. 2014, vol.38, no.3, pp. 805-822. DOI: 10.1111/14682427.12133

7. Cross A. (ed.). A People Passing Rude: British Responses to Russian Culture. Open Book Publ., 2012. 348 p.

8. David-Fox M. Showcasing the Great Experiment: Cultural Diplomacy and Western Visitors to the Soviet Union, 1921-1941. Oxford; New York, Oxford University Press Publ.,, 2012. 396 p.

9. Douglas A. J. A Visit to Russia. The Architect and Building News. 3 December, 1953, pp. 682-688.

10. Hollander P. Political Pilgrims. Travels of Western Intellectuals to the Soviet Union, China and Cuba, 1928-78. New York, Oxford University Press, 1981. 544 p.

11. Kazakova O. The Fight against Superfluity in 1930-1950s. Arkhitektura stalinskoi epohi: opyt istoricheskogo osmisleniia (Architecture of the Stalin Era: The Experience of Historical Comprehension). Moscow, 2010. 496 p. (in Russian).

12. Knight C. Mrs Churchill Goes to Russia: The Wartime Gift Exchange between Britain and the Soviet Union. Cross A. (ed.). A People Passing Rude. British Responses to Russian Culture. Open Book Publishers, 2012, pp. 253-267.

13. Lipkin M. Soviet-British Intellectual and Cultural Interactions during the "Cultural Détente": The End of 1950s - Beginning of 1960s. Electronic scientific and educational journal "History”, 2015, vol. 6, no. 10 (43). DOI: 10.18254/S0001328-9-1 (in Russian).

14. Lopatkina K. Bastardi kulturnykh sviazei. Internatsionalnye khudozhestvennye kontakti SSSR v 1920-1950kh (Bastards of Cultural Relations: International Artistic Contacts in the USSR, 1920-1950s). Moscow, Museum of Contemporary Art Garage, 2019. 180 p. (in Russian).

15. Lubetkin B. Soviet Architecture - Notes on Development from 1917 to 1932. Architectural Association Journal, vol. 72, no. 806, November, 1956, pp. 260-264.

16. Malich K. "I am Amazed by Everything I See": Trips of British Architects to the USSR. On the Question of the Perception of Soviet Architecture and the Features of Communication between English and Soviet Architects in 1920-1930s. Vestnik of Saint Petersburg University. Arts, iss. 10(3), 2020, pp.475-487. DOI: 10.21638/spbu15.2020.306 (in Russian).

17. Russian Architecture and Building 1955. RIBA Journal. March, 1956, pp. 182-189.

18. Stern L. Western Intellectuals and the USSR 1920-1940. From Red Square to the Left Bank. Abingdon, Oxon, New York, Routledge Publ., 2006. 276 p.

19. The Architect's Journal. October, no. 1, 1953, p. 398.

20. Stephen V. Ward. Soviet Communism and the British Planning Movement: Rational Learning or Utopian Imagining? Planning Perspectives, iss. 27-4, 2012, pp. 499-524. DOI: 10.1080/02665433.2012.705127

21. Yorke F. R.S. Russia. Architect's Diary. The Architect's Journal. October, no. 1, 1953, pp. 400-404.

\section{Sources}

1. Royal Institute of British Architects (RIBA) Archive. The UK. London. AP 66/65.

2. State Archive of the Russian Federation (GARF), fund 5283, inventory 15, cases 352, 383, and 407.

3. Russian State Archive of Literature and Art (RGALI), fund 674, inventory 2, case 99; inventory 3, cases 241, $623,1307,1321$, and 2125 . 
Title. Two Delegations of British Architects in the Soviet Union: Professional Contacts between British and Soviet Architects at the Beginning of the Khrushchev Thaw

Author. Malich, Ksenia Aleksandrovna - Ph. D., senior lecturer. National Research University Higher School of Economics. Kanala Griboedova nab., 119-121, 190068 St. Petersburg, Russian Federation. kseniamalich@gmail.com ORCID: 0000-0003-4213-9468

Abstract. The article is devoted to the history of professional contacts between British and Soviet architects at the beginning of the Khrushchev Thaw period. A great deal of work that has been carried out in recent decades in the field of studying the activities of the VOKS and Soviet cultural international politics, as well as a discussion about the features and the role of Soviet architectural practice in the 1930-1950s, prompt us to look at this subject with special attention. After all, the reasons, circumstances, and the very nature of professional communication between Russian architects and their foreign colleagues help us to take a fresh look at the peculiarities of the development of post-war architecture. Before World War II, some British architects, although they considered the possibility of travelling to the USSR in hope of getting an order, mostly came here out of curiosity. However, in the 1940s, the context of the perception of the Soviet art changed. The tasks of post-war reconstruction were common to both Great Britain and the USSR: the industrialization of the construction sector, mass housing, the redevelopment of cities, and the restoration of damaged historical monuments. Intensive communication between the VOKS architectural section and English architects already during the war years predetermined the mutual interest that flared up in the post-war period. The first trips, which took place in 1953 and 1955, as well as their results, have been reviewed in this study.

Keywords: VOKS, cultural diplomacy, Soviet architecture, British architecture, Lubetkin, London architectural Association

Название статьи. Две делегации британских архитекторов в СССР: профессиональные контакты между английскими и советскими архитекторами в начале периода «оттепели» ${ }^{17}$

Сведения об авторе. Малич Ксения Александровна - кандидат искусствоведения, старший преподаватель. Школа дизайна НИУ ВШЭ - Санкт-Петербург, наб. канала Грибоедова, 123, Санкт-Петербург, Российская Федерация, 190068. kseniamalich@gmail.com ORCID: 0000-0003-4213-9468

Аннотация. Статья посвящена истории профессиональных контактов британских и советских архитекторов в начале периода «оттепели». Большая работа, которая ведется в последние десятилетия в области изучения деятельности ВОКС и советской культурной международной политики, а также дискуссия об особенностях и роли советской архитектурной практики 1930-1950-х гг., побуждают взглянуть на этот сюжет с особым вниманием. Причины, обстоятельства и сам характер профессионального общения российских архитекторов с зарубежными коллегами помогают нам по-новому взглянуть на особенности развития послевоенной архитектуры. До Второй мировой войны отдельные британские зодчие хотя и рассматривали возможность оказаться в СССР в надежде на получение заказа, тем не менее в большинстве случаев приезжали сюда скорее из любопытства. Однако, в 1940-е гг. контекст восприятия советского искусство изменился. Задачи послевоенной реконструкции оказались общими в Великобритании и в СССР: индустриализация строительного сектора, строительство массового жилья, перепланировка городов, реставрация пострадавших исторических памятников. Интенсивное общение между архитектурной секцией ВОКС и английскими зодчими уже в годы войны предопределила взаимный интерес, вспыхнувший в послевоенный период. Первые поездки, состоявшиеся в 1953 и 1955 гг., а также их результаты, рассмотрены в данном исследовании.

Ключевые слова: ВОКС, английская архитектура XX века, советская архитектура, культурная дипломатия, Любеткин, Лондонская архитектурная ассоциация

17 Публикация подготовлена в ходе/в результате проведения исследования/работы (№ 20-04-029) в рамках Программы «Научный фонд Национального исследовательского университета «Высшая школа экономики» (НИУ ВШЭ)» в 2020-2021 гг. 